\title{
An Issue of Scale: The Challenge of Time, Space and Multitude in Sustainability and Geography Education
}

\author{
Frode Skarstein ${ }^{1, *(\mathbb{D} \text { and Lili-Ann Wolff }}{ }^{2}$ \\ 1 Department of Education and Sports Science, University of Stavanger, 4036 Stavanger, Norway \\ 2 Faculty of Educational Sciences, PB 9, 00014 University of Helsinki, Helsinki, Finland; \\ lili-ann.wolff@helsinki.fi \\ * Correspondence: frode.skarstein@uis.no; Tel.: +47-5183-1416
}

Received: 7 December 2019; Accepted: 21 January 2020; Published: 23 January 2020

\begin{abstract}
The field of geography is important for any sustainability education. The aim of geography education is to enable students to understand the environment, its influence on human activity, and how humans influence the environment. In this article we present a study on how the interplay between the three pillars of sustainability thinking (environment, society and economy) play out on smaller and larger scales of time, space and multitude in geography education. In this paper, we argue that central issues in high quality sustainability education in geography relates to students' deeper grasp of how to shift between magnitudes of time, space and multitude patterns. We show how an appreciation of many core issues in sustainability education require students to understand and traverse different magnitudes of the scalable concepts of time, space and multitude. Furthermore, we argue and exemplify how common sustainability misconceptions arise due to an inability to make the cognitive shift between relevant magnitudes on these scalable concepts. Finally, we briefly discuss useful educational approaches to mediating this problem, including the use of digital tools in order to allow geography teachers to facilitate the students' better understanding of different magnitudes of slow, fast, small and large scale entities and processes.
\end{abstract}

Keywords: geography education; sustainability education; education for sustainable development (ESD), misconceptions; preconceptions; alternative conceptions; magnitude; issues of scale; mental models; digital tools; dialogic teaching

\section{Introduction: The Sustainability Aspects of Geography}

At the time of writing this paper, over 200 bushfires are raging across large tracts of the Australian continent. An area of over $60,000 \mathrm{~km}^{2}$ around the country has been burnt during the past month, and there is no real end in sight. The fires have killed 24 people so far, destroyed over 1500 homes, and estimated to have killed close to 1 billion animals (this estimate excludes non-vertebrate lifeforms such as insects and plants, for which the number of killed organisms is simply unimaginable) (e.g., [1-4]). Most people will agree that this sort of natural disaster, which will most likely have anthropogenic influences, is large in extent and effect, and perhaps unprecedented. Yet most will struggle to make sense of the extent of this natural disaster. The size of the fires, the number of animals killed and the extreme rarity of fires on this scale is far beyond the realms of everyday human experience. The purpose of the current study is to draw attention to the issue of scale in sustainability thinking within geography and how issues of scale should be taken into consideration in sustainability education.

Many contemporary researchers argue that planet Earth has reached a new geological epoch, which they call the Anthropocene (e.g., [5-7]). By distinguishing this epoch, they want to emphasise the strong human-influenced (anthropogenic) changes in Earth's physical features. These changes occur in the atmospheric, geologic, hydrologic, biospheric and other earth systems with obvious impacts on 
the social spheres. Simultaneously with ecologic knowledge, there is a need for human cooperation, democracy, and social justice (e.g., [8]), and humans aware of ethics, and changed practices based on transformed political power and actions [8]. The field of geography has a significant role to play in the Anthropocene and needs to develop and reshape sustainability education that meets the needs of both the present and an unknown future.

The two main branches of geography, physical and human, provide knowledge of crucial relevance for an education towards most of the 17 UNESCO sustainable development goals [9]. With physical geography drawing mostly on the natural sciences and human geography relying more on the social sciences and humanities, together they provide a methodological and conceptually-rich and multifaceted view of human societies. These two views show how societies are organized and how they interacted/will interact with the natural environment in the past, today and in the future. Therefore, the study of geography integrates and develops our understanding of society, economy and the environment, the three traditional pillars of sustainable development thinking.

Good geography education should consequently provide a fruitful immersion of students into knowledge and understanding of how human societies and economies develop, interact with and change the natural environment in time and space. However, Rosling et al. [10] argues that humans tend to see the vast amount of information about the reality through a filter of unconscious and predictable biases. Therefore, the most dramatic information easily tramples over critical considerations and fact based on actual scales and numbers.

The issue of scale is a known challenge to science education in general (e.g., [11-13]), and in the current paper we argue that it is of particular importance with regards to students' understanding of sustainability and thus both physical and human geography. That is, students' and teachers' ability to manoeuvre mentally along large spans of time, space and multitude is a core component of obtaining a deep understanding of sustainability thinking.

Concepts of scale permeate the study of both human and physical geography. Given the multiple understandings and usages of scale, it can be a challenging concept to engage. A useful distinction between different approaches to the concept is that adopted by Montello [14], through which he has a delineation between the cartographic, analysis and phenomenon scales. Cartographic scale is the relationship between the dimensions of a constructed representation and the reality it represents, such as maps and physical models. Analysis scale refers to at what level or unit, for example town or nation-level, a given issue is analysed. In this paper we mainly engage with the third understanding of scale, namely the phenomenon scale, which can be understood as the dimensions in which structures or processes exist, regardless of how they are studied or represented. Our concern in this paper is with understanding how students' misconceptions in sustainability education within geography often have their roots in issues of how they perceive phenomenon scales. In particular, we argue that the concept of time, space and multitude are important scalable dimensions that it would be useful to include in the sustainability education of geography.

The challenge of helping geography students to develop a deep understanding of geological time, microscopic and vast spans of space and immense numbers is nothing new to geography education (e.g., [15-17]). In particular, Cheek et al. [15] have formulated the conceptual challenges of scale for students in geography education. Yet, it is still a topic that receives too little emphasis and research, and virtually no attention has been paid to the issue of scale in sustainability education.

By first exploring sustainability issues of relevance to geography and then giving examples on three topics of interest, namely greenwashing, shifting baselines and climate change education (see Section 7), we illustrate how issues of scale can influence how well students perceive, understand and make sense of sustainability topics. We argue that many common misconceptions in this context relate to the inability of students to identify relevant scales in the process or phenomenon at hand. We then attempt to suggest important scalable dimensions in geography and sustainability education and identify relevant research and ideas on how to improve students' understanding of these dimensions of scale, with special attention to the usefulness of digital tools in this context. 
Thus, the purpose of this literature-informed perspective paper is, firstly, to identify relevant scales to promote geography students' deep understanding of sustainability, and secondly, to suggest creative and useful educational approaches to teaching about scale in geography.

\section{Core Issues and Challenges of Sustainability Education in Geography}

According to our definition, sustainability education is about promoting both ecological literacy and social justice understanding. It is practice oriented [18] and critical [19]; it draws attention to the preconceived assumptions that governs human actions; it intersects well-established beliefs and encourages students to think independently $[19,20]$. Sustainability education is a process in which students develop their own ability to analyse, negotiate, search for alternatives and make choices [21]. They must deal with issues such as equality and constellations of power and are encouraged to criticize the systems they are a part of. This acknowledges that sustainability education is more than content knowledge within the various topics of science education and recognizes that its holistic and transformative nature depends upon students developing a sense of agency and empowerment. That is, students need not only to be able to understand but also how to reflect, feel and act critically.

Geography education has often been the school subject responsible for sustainability education [22]. However, the ways sustainability is implemented in geography education vary a lot, especially at the university level (e.g., [23]), likewise the names of the courses are heterogenous [23]. Nevertheless, geography has much unused potential when it comes to sustainability [22,24]. This might have to do with how sustainability like geography lies between two disciplines taught by universities: social sciences and arts, as well as science. Nonetheless, the quest for sustainability deals with holistic approaches and questions where human, social and nature topics encounter. Like sustainability, geography also needs to focus on ecological, social, economic and political views. The fact that geography focuses on global issues and on scales (temporally and spatially) are other reasons to why sustainability suits geography so well [22].

Geography as a school subject, defined broadly as the study of the landforms, features, inhabitants and phenomena of the Earth, touches on virtually all aspects of sustainability thinking (e.g., [16,24-26]). In physical geography sustainability-related issues would include an understanding of geology and the geological processes of the Earth, resource distribution, landforms, weather and climate. Issues of the importance of sustainability in human geography involves the distribution and changes of populations and population demographics, resource usage, environmental impact of human activity, resource and pollution-related conflicts, poverty issues, and political governance.

Gradually, geography studies and geography education have been shifting focus from viewing the world objectively to a subjective view. Accordingly, the students become participating agents in world processes; geography describes processes in which the students relate to places through their involvement in politics, ethnic cultures, social groups, patterns of consumption, et cetera (e.g., [27]). A crucial geography task is then to promote the students' understanding of their own potential as creative citizens in the global economy and culture [28] and to imagine alternative futures [29].

Connected to a higher-order level of student thinking are the dichotomies and complexities arising from present and future social activities related to sustainability in geography education. These include potential futures-orientation, systems thinking, local vs. global issues, individual agency vs. governmental control and social justice (e.g., [25,26,30-32]). Sustainability related issues are also scientifically, especially mathematically, extremely complicated. For example, if there is a decrease in the $\mathrm{CO}_{2}$ level in the atmosphere, it is unclear how the planet will respond [33]. This is a non-linear problem with a multitude of synergetic interactions, with implicit unpredictability.

The complexity of geography questions is not only obvious at a physical level, but also at a social level. Sustainability and geography issues are connected to opposing voices, various ideas and belief systems and conflicting values $[27,34]$. The world is no uniform space, and for that reason it is important to promote global views and global efforts in geography $[27,34,35]$. In a sustainability education respect, "global" means that the students become critically aware of planetary social differences, develop deep 
cross-cultural understanding and become familiar with and raise critical awareness of the conditions in other parts of the world than their own (e.g., [35]). Global understanding also includes perspectives of geography and temporal and spatial thinking skills. Initiating online collaboration can be one way to offer students opportunities to share learning experiences with students living under different conditions [35].

From this general list of sustainability-related topics of geography, it becomes clear that in addition to solid content knowledge, a geography approach to sustainability can offer an education that develops competencies which can empower and enable individuals to engage in socio-political processes of importance to sustainability. Yet, single geography courses are not enough to shed light on all the complex sustainability dilemmas. According to Fox et al. [36] resilience building and human adaptation to the Anthropocene need broad interdisciplinary understanding that connects social and environmental challenges. Therefore, an interdisciplinary approach could widen the perspectives. The geography programs can acknowledge this by arranging courses with experts from many fields and by participating in interdisciplinary projects, among other things [37].

\section{Scalable Dimensions of Interest in Science, Geography and Sustainability Education}

As illustrated by the core topics presented above, issues of scale are common in sustainability education. It is possible to imagine an endless number of scalable quantities in nature. In this paper we aim to explore three important categories of scalable axes of relevance to sustainability education, namely time, space and multitude.

Time is a concept that at first appears easy to grasp, but which is all but easily pinned down. Perhaps a useful definition is that time is a dimension that defines the sequence of events. Time allows one to map and refer to current and past events, and to imagine futures. It is a dimension which enables quantification of duration, from very short to very long events. Students of geography (and other subjects) should be able to make sense of timespans stretching back to virtually the beginning of time whilst also be able to visualize many potential futures. The examples of climate change education and shifting baselines below (see Sections 7.1 and 7.3) illustrate that students' conceptions of time at different scales and magnitudes influence is important in how students make sense of sustainability issues.

Space is defined as "a boundless, three-dimensional extent in which objects and events occur and have relative position and direction" [38]. The concept of space in natural science describes spatial distances, areas and volumes using continuous measures or terms such as "close", "distant", "short", "long", "small" or "large". It can be considered to be a tangible and readily understood concept, yet when we attempt to make sense of smaller and larger things than our everyday perceptions allow us to experience, scale issues appear. In a single science lesson, students are regularly challenged to jump from spatial scales in which they make sense of elementary particles to scales that make them struggle with interstellar distances. The spatial scales are also related to other continuous quantities, such as volume and density. In the examples of climate change education and greenwashing efforts (see Sections 7.1 and 7.2 below), students' conceptions of these issues will be influenced by their ability to move along different scales and magnitudes of volume and density, relative sizes and distances.

Human geography distinguishes between the concept of space and the concept of place. Yet, there are many views of this distinction [39]. According to a study of many other authors, Saar and Palang divides space into three forms. Firstly, they separate perceived space, like invisible 'bubbles' that people live inside. These spaces are complex spatial organizations of practices for activities in buildings, neighbourhoods, cities, etc. To these spaces belong the world economy and global geopolitics. Secondly, they refer to space as conceived space, knowledge primarily produced by discourses of power and ideology. Various professionals, such as engineers or researchers create and use such spaces. The third form, 'thirdspace', of spaces is the most difficult to grasp, since there the abstract and the concrete meet. They can be understood as mental spaces influenced by wider social, economic and political processes. Place, on the other hand, is a location created by experiences. In physics, Aristotle [40] said 
that place definitely is something, but it is hard to say what is its essential nature. According to Saar and Palang [39] a place is multidisciplinary and socially constructed:

"Place for us is socially constructed and operating, including interaction between people and groups, institutionalized land uses, political and economic decisions, and the language of representation" [39] (p. 7).

Multitude is a form of quantity which describes the number of discontinuous entities under study. Multitudes are measured by the process of counting objects, and they are expressed using integers or terms such as "few" and "more". As with the concept of space, the concept of multitude is easily graspable when exploring quantities found in everyday experiences, yet significant challenges arise when one attempts to make sense of very large numbers, such as human population size. Furthermore, being able to meaningfully compare large multitudes is key to grasping issues of climate change and the true nature of greenwashing activities, as explored further in the examples in Section 7.

As humans, we have always had a relationship to time, space and multitude, and their relevant combinations. For example, a particularly important combination of time and space is the speed, direction and acceleration of objects with which humans seek to react to, be that catching moving prey, avoiding a thrown rock or navigating complex terrain while running.

Time, like space, is something that most people are familiar with, and yet it might be difficult to answer a question about what time is. Time relates to many topics, not the least language. In many languages, the verbs explain what has happened, what is happening now and what will happen (e.g., English), but in other languages, the adjectives can also denote different modes of time (e.g., Japanese) [41]. Physical scientists view time as either absolute or relational [42]. According to the absolute view of time, time like space, forms an arena of physics. That means that all material processes have backgrounds of 'time' whereas relative time is dependent on, that is related to, matters [42]. Roark [43] calls time one of the knottiest conceptual problems in philosophy. Aristotle relates time to motion. Yet, he argues to and fro and his interpretation is all but easily grasped (e.g., [43]).

"Now we perceive movement and time together: for even when it is dark and we are not being affected through the body, if any movement takes place in the mind we at once suppose that some time also has elapsed; and not only that but also, when some time is thought to have passed, some movement also along with it seems to have taken place. Hence time is either movement or something that belongs to movement. Since then it is not movement, it must be the other." [40].

A student of geography will encounter issues of scale related to time, space and multitude in virtually every aspect of geography, be it physical or human geography. It is beyond the scope of this paper to provide an exhaustive overview over all such issues.

\section{Scale and Sustainability}

The core assumption of sustainability thinking is that all human beings have the same right to live good and fair lives by means which, if scaled to a global level, do not transgress the biophysical boundaries of the planet. This means that an understanding of social, environmental and economic challenges at and across local and global scales is crucial for students to obtain the knowledge, incentive and ability competent sustainability citizens will need. At the core of developing such deep knowledge lays the ability to engage with relevant issues of scale along axes of time, space and multitude. The subject involves embracing related issues on hugely different scales, such as individual agency and governmental policy, individual footprint and human population size effects on the world, lifespans of humans/societies/cultures/nations and local and global pollution effects, imagining alternative futures, unhinged from past trajectories. Therefore, sustainability is a subject more or less impossible to handle within the scales of daily experiences. Immediately, the many-faceted topic of sustainability requires learners to be confident in scaling orders of magnitude all of time, space and multitude. 
The first core challenge in sustainability thinking is an ability to see and understand relationships between local and global issues and actions, one's own welfare and prosperity in contrast to how other people live. The second is the challenge of short-sightedness as opposed to long term thinking, and the third is the individual's choices in contrast to decisions made at regional, national and global levels (e.g., [44-46]). Familiar challenges within sustainability education are how social and environmental problems are often perceived as challenges only related to humans far away in a distant future. These are all interdisciplinary challenges which require a well-developed ability to choose useful perspectives, apply relevant magnitudes and to scale axes of time, space and multitude cognitively.

Sustainability thinking challenges learners' ability to scale their empathy and sense of justice, equality and fairness to encompass family, friends, community and virtually the whole of humanity. Similarly, the ability to scale the environmental impact of one's own lifestyle to the environmental impact of 7.6 billion people acquiring a similar standard of living is another useful exercise. Furthermore, grasping historical human population growth, a cornerstone of sustainable development thinking, is also riddled with challenges with regard to understanding both quantity and rates of change, in order to understand the strain on environmental capacity caused by human population growth and increasing global standards of living.

From the preceding few paragraphs it is obvious that within sustainability thinking, the challenges of understanding how to navigate across magnitudes of space, time and multitude are intertwined.

\section{Scale and the Case of Population Growth}

Social sustainability connects to the challenges of scope and scale [47]. However, it is difficult to find common frameworks to measure local, regional and international levels of population-related issues. These issues are inextricably linked to the development itself. Elements that are usually thought of as functioning on local or global levels have become extremely complex [48,49]. Even if different processes may be going on in individual countries, environmental and demographic changes are interrelated and have implications for other countries far away, and for natural resources across the world [49].

Demographic and environmental changes exert influence simultaneously; they are affected by environmental conditions and climate change, shaped and reshaped by economics, employment and poverty, and in turn they affect health, education, sanitation, food, energy, and other demographics [49]. Population growth, ageing, urbanization and migration might demand totally new ways of considering and conceptualizing human development and demographic changes [49]. According to Güney [50], the level of development in a country affects how much its population growth affects sustainability; consumption in rich countries is much higher than in poor countries in relation to the relative population sizes. It is also higher than the goal of achieving a sustainable consumption level [50]. A major distinction between countries and regions is that while poor countries have contributed less than rich countries to climate change, they are more exposed to the negative effects [49]. The population growth of different age groups also has different effects on sustainability [49].

Even if there is space for three billion more people on Earth, there are not enough spaces that are safe from natural and human-caused hazards. There are also limits to how much megacities can grow before they become unmanageable. Space is not the biggest problem with a big world population, but availability of necessary needs [51], and this is more demanding to calculate and foresee. Many citizens of the world already live under stress because of lack of food, shelter and clean drinking water [51]. The reason that so many lack basic means of subsistence and livelihood has connection to neoliberal world capitalism and corruption [8].

Without redistribution and a new world economy this problem cannot be solved. In the report from United Nations Development Programme 2019, it says that "assessing inequalities in human development demands a revolution in metrics" [52] (p. 3). This means that the world needs a new way of measuring using clearer concepts, a combining of data sources and sharper data tools. However, 
even it is possible to measure and predict better, the climate problem has first and foremost to be met by changed policy [53]. This is obvious in the Australian bushfire situation [54].

Global warming is a major factor affecting the human population socially and economically, including increased unpredictability of the future. Scientists estimating the effects of a rising sea level reach differing conclusions [51]. Since the effects of climate is nonlinear (disproportionality between causes and effects), the future impact of global warming is unevenly distributed around the planet, with different populations being affected differently $[53,55]$. Global warming and its outcomes also affect a population's subgroups differently [55]. In addition, global warming may have an influence on sexual behaviour and fertility rates [55].

Yet, students should not only view humans as vulnerable victims, but they also need to see humans as empowered and able to change the direction of the developmental process [53]. "We do have a choice, and we must exercise it now" [52] (p. 4) has to be the leading proposition in education. Since measuring and counting will not be easy, ethical discussions and multiple ways of comparing statistics is a way to approach the development problems. The United Nations, for example, produces a lot of digital data about the state of the world in figures that can be used in learning situations to base discussions on. The sustainability dilemmas are complex, even 'hypercomplex', which means that they are infused with constraints and emergence, interdependent and dependent, congruous and incongruous [53]. Therefore, the required methods are also complex, encompassing multiple disciplines including especially natural science, social science and philosophy, and employing both quantitative and qualitative methods [53]. Geographers who want to study the multiplicity of sustainability need a steady companion of philosophy in addition to human geography and natural geography. Many contemporary sustainability problems relate to ethics (e.g., [56]).

Marston et al. [48] have gone as far as to suggest a total elimination of the concept of scale when studying human geography. Instead they suggest a flat ontology. It is difficult to find common frameworks for measuring local, regional and international levels of social sustainability. Perhaps it is not even possible to compare rural and urban contexts, not to mention finding useful tools to compare northern and southern countries. The variability in individual countries in spatial population distribution may already be high and differences across countries due to internal reasons can outline distinct demographic patterns at the regional scale [57]. Multiple, non-linear forces shape natural balance and migratory movements in unique ways on different temporal and spatial scales [57].

\section{The Issue of Scale in Science Education}

"If the universe is queerer than we can suppose, is it just because we've been naturally selected to suppose only what we needed to suppose in the Pleistocene of Africa? Or are our brains so versatile and expandable that we can train ourselves to break out of the box of our evolution? Or finally, are there some things in the universe so queer that no philosophy of beings, however godlike, could dream them." [58].

Many of the misconceptions students bring into geography studies, and particularly within issues pertaining to sustainability, relate to how they are able to understand the issue of scale, and how they are able to make cognitive jumps between different magnitudes of time, space and multitude. The issue of scale is a major, yet under communicated, hurdle of science education at any educational level and every topic [11-13,59-61]. As an incredibly successful approach to understanding the physical reality around us, the natural sciences seek to explain aspects of reality on vastly different dimensions of time and space: from the smallest elementary particles to the size of the universe; from the age of that same universe to the speed of light. Scale is about grappling with the smallest and the largest, the fastest and the slowest, the few and the many. It also has bearing on phenomena as unrelated to each other as the understanding of molecular structures to how we relate to climate change, how we visualize urbanization to how we perceive the size of the human population. The ability to make relevant sense in these different contexts depends on our cognitive propensity for scaling [13]. 
It is an important skill to be able to move cognitively between an understanding of the time in minutes it takes for light to reach us from our own sun, to the time in hundreds of thousands of years light has to travel to reach us from other stars. Being able to view issues at their proper scales has significant implications for how humans as individuals, as societies and as humanity, understand the world around them and consequently how they view the pressing issues of the current epoch. Take as an example a number as large as 7.6 billion, the current human population size. This is a number that is more or less cognitively impossible to comprehend, yet it is a number of dire importance for any issue of sustainability.

Most students have not developed a good cognitive grasp of how enormous our current population is, and how extremely rapid our population has changed over the past few hundred years. Since humans evolved into being as a species around 200,000 years ago, it took most of that time to reach a worldwide population of about 1 billion humans. Yet, it took only 200 more years to explode into a population of nearly 8 billion people. Such a rapid change in the number of people on the Earth is simply mind boggling, and it is perhaps both the clearest and most pressing issue of scale, further complicated by the enormous heterogeneity in the carbon footprint and levels of consumption of people in the Global North and South. When faced with such large numbers, we are left grappling with how to make sense of such multitudes.

It falls on the geography teacher to help students move along scales of time and space in a manner which makes sense to the students, and to help them learn how to understand large multitudes and how to choose the most useful orders of magnitudes, with the goal of enabling them to develop a deep sense of scale.

\section{Alternative Conceptions in Geography and Sustainability Education}

Common challenges to student learning and meaning making in science, including geography, are students' alternative conceptions (here used as ideas that people have which are inconsistent with scientifically acceptable ideas) (e.g., [62,63]). The subject of alternative conceptions in science education exists within the framework of constructivist thinking, where learning occurs as the learner actively constructs meaning by reinterpreting current conceptions (e.g., [64-66]). Alternative conceptions can arise through informal learning experiences occurring outside the classroom and from misunderstandings arising during education [67]. Consequently, students enter geography education with mental models of geography issues constructed from everyday experiences which align or correspond to varying degrees with the currently accepted geography narrative. Furthermore, during their education students may construct mental models that conflict with or only partly overlap with current geographical thinking. Consequently, high-quality teaching requires teachers to be aware of the relevant mental models their students have constructed, and by which means they are best moved towards the current geography theory, taking into consideration the common misunderstandings usually encountered in the educational process $[63,68]$.

In an extensive review of recent literature, Francek [69] lists over 500 misconceptions in geoscience, of which a large proportion relates directly or indirectly to issues of physical geography of relevance to sustainability education. These misconceptions include topics such as: formation, distribution and origin of fossil fuels; formation of modern landscapes; formation and distribution of natural resources; causes, frequency and distribution of vulnerability to climatic changes; age of the Earth and appearance of geological features, species evolution; understanding of geological time periods; geoscience dating techniques; age and evolution of the human species; causes and frequency of mass extinction episodes; causes and occurrence of megafauna extinctions; uniformitarianism; formation and movement of groundwater; speed of and processes driving continental drift; sizes of continents relative to familiar local distances; driving forces of and time scale of erosion processes; frequency and causes of flooding; anthropogenic and divine influence on landscapes; soil origin, distribution and erosion speeds; and relative magnitude of local versus global distances. 
Several studies have shown that alternative conceptions are common with regards to climate change [70-75]. These alternative conceptions relate to the causes and frequency of changes to the climate, but also the issues of immediacy, concern and consequence of current anthropogenic climate change. Students' alternative conceptions regarding issues such as causes of and distribution of world hunger issues are also obvious, as are dilemmas related to social, temporal and spatial issues surrounding environmental commons [76].

Geography and geography education, as well as sustainability, connect remarkably with development issues. Such issues depend on spatial variability, place dependent processes, processes operating through intersecting spatial scales, situated agency (who shapes the development?) and they also concern the nature-society relationship [27]. Questions like gender, ethnicity and competition and their relations to the dominant worldview, global and place specific political struggles as well as historical power constellations become relevant for the understanding of and critical reflection in geography. A common example of a topic in which all these elements are visible is the production, distribution and consumption of food. It is possible to study food issues as a geography theme on the scale of a household, village/city, nation state or as a global phenomenon [27].

This short list of sustainability related challenges and alternative conceptions connected to geography is far from exhaustive and it is only meant as an illustration of how common issues can be traced to challenges directly or indirectly related to how students perceive time, space and multitude.

\section{Three Tangible Issues of Sustainability Education in Geography and the Role of Scale}

To illustrate how issues of scale can be seen as important challenges to sustainability education, we explore three examples of topics of relevance to sustainability thinking.

\subsection{Climate Change Education}

Understanding the enormous challenge of human-induced climate change and its challenge to human society is a relevant and illustrative example of a complicated issue of sustainability education. Firstly, the natural science behind our understanding of how we influence the climate is complicated and requires geography students to understand key concepts of several different science disciplines, and how to bring them together into one cohesive story. Secondly, the challenge of human induced climate change poses for human society is a political and cultural issue, with questions and answers about the degree of reality, urgency and importance, as well as potential solutions, goals and desired futures, distributing themselves along fairly well understood political and cultural divides [77-84].

Students construct many misconceptions when trying to familiarise themselves with the climate change issue $[72,74,75,85]$, and it can be argued that many core climate change-related misconceptions arise from how students perceive phenomena and processes at different scales. For example, students struggle with understanding how changes in the levels of $\mathrm{CO}_{2}$ in the atmosphere can influence the greenhouse effect, despite this gas only contributing to a fraction of a percentage of the gases in the atmosphere. Similarly, how can humans bring about carbon emissions large enough to drive this global process? Many students also fail to understand how unprecedented the current observed rate of change in $\mathrm{CO}_{2}$ levels are, compared to previous fluctuations.

Another common challenge to climate change education is to grasp how far into the future the $\mathrm{CO}_{2}$ emissions of today will remain in the atmosphere, and consequently how current emissions could be changing the Earth for hundreds and thousands of generations to come. How a global average temperature increase of $2.0^{\circ} \mathrm{C}$, an increase in temperature smaller than the temperature difference between the top of a dining room table and the floor, can have catastrophic consequences for ecosystems all over the world is also a common conceptual challenge to students. It is worth noting that many of the challenges to climate change understanding listed here are used by climate skeptics as arguments against the idea of human induced climate change [86].

Climate change education is also made difficult with regards to students' conceptions regarding social and economic aspects of the climate change challenge. To envision the social and political 
components of the solutions to this crisis, students need to cope with issues such as individual versus governmental action, the current and changing carbon footprints of people and countries of the global south compared to the global north.

These few and selected examples of misconceptions in climate change education are all related to how students can perceive quantities, sizes, distances, volumes, rates of change and spans of time smaller or larger than those offered by the range of everyday human experience.

\subsection{The Scale-Issues of Greenwashing Efforts}

An important aspect of sustainability education is information literacy, including critical thinking and source criticism. Perhaps particularly within geography education, students of sustainability must be adept at critically evaluating the validity and intent of a host of information sources, given the strong political and economic interests involved in sustainability questions. Tangible examples of such situations are the greenwashing efforts of various companies and governments involved in activities that negatively affect the environment $[87,88]$. Greenwashing can be understood as the act of spreading disinformation by an organization to present an environmentally responsible public image (Concise Oxford English Dictionary, 10th Edition). Greenwashing attempts by interest groups are common and are often aimed at attempting to shift attention towards small and symbolic green efforts, and consequently away from the larger environmental challenges of the relevant industry. Furthermore, greenwashing efforts tend to emphasize benefits close to home and ignore or discredit claims of disadvantages further afar.

Petroleum companies and governments with oil-dependent economies are, in the current climate challenge discourse, known to resort to greenwashing arguments [89,90], of which the long-term efforts of the Norwegian government and Norwegian oil companies are useful examples [91]. For several years the idea that Norwegian oil is preferable to oil produced elsewhere due to the manner in which its oil is produced, i.e., extracted and refined, has been promoted in Norway [92,93]. That is, they claim that the $\mathrm{CO}_{2}$ emissions needed to produce a given amount of crude oil or gas are higher elsewhere compared to the Norwegian oil production. Although this has an element of truth to it [94], it underscores the fact that the $\mathrm{CO}_{2}$ emissions from production accounts for only about $5 \%$ of the total $\mathrm{CO}_{2}$ emissions of fossil fuel usage. Consequently, the benefits of Norwegian oil in a bigger picture are somewhere between small to insignificant, and definitely irrelevant in a post-fossil fuelled future. Similar examples are efforts by oil companies to over-emphasize their small renewable energy departments whilst under-communicating the degree to which they still base most of their revenue on fossil fuel extraction [91].

Based on this, the ability to identify company or governmental greenwashing efforts requires the ability to identify the correct frame of comparison. That is, it is important to understand what the relative effect of the greening effort of a company is compared to its regular activities. Similarly, who are the beneficiaries of any benefits from such greening efforts, and across what periods of time are these efforts relevant?

\subsection{The Concept of Shifting Baselines and Its Relevance to Sustainability Education}

The shifting baselines syndrome relates to how our perception of time influences how we perceive change over spans of time [95]. When looking at an environmental phenomenon or process that is undergoing slow change, as time passes, humans tend to align their perception of what is normal (i.e., the baseline) to the current situation [96]. The consequence of this is that accepted levels of environmental conditions are gradually being lowered.

Such shifting baselines in our perception of what is normal can include climatic shifts [97], involving seasons, temperature change, snow distribution, frequency of bushfires and precipitation patterns. It can involve aspects of natural history [98-101], as exemplified through how we perceive changes in biodiversity, commercial fish population sizes, migratory bird arrivals, tick prevalence and 
the extent of urban sprawl. This could influence management goals and public perception and support of management efforts [95,102-106].

Our perception of human ways of living also experience shifting baselines, such as our expectations with regards to disease prevalence, standard of living and consumerism. Examples of shifting baseline syndrome in conservation efforts are plentiful [99,107-109], and the consequences this might have for our ability to create an awareness, understanding and accepting of anthropogenic change need to be explored further [110]. If we constantly adjust our understanding of what we consider normal to describe the current situation, our ability to notice long term change will be severely limited [111].

To avoid shifting baselines, and instead obtain a deeper understanding of how various aspects of culture, human life and the surrounding environment are changing, requires an ability to view change through time framed on scales beyond personal and individual experiences.

\section{Geography Education for Scale Understanding}

A handful of studies have been published on how the concept of scale is of consequence in science and more specifically, geography education [11,15,17,59-61,112-114]. A common theme in most of these studies touches on the importance of experience in determining a student's proficiency at conceptualizing scale and shifting magnitudes. Two kinds of experience are emphasized as increasing the ability to handle scale-shifts: direct experience with the relevant dimensions at different magnitudes; and, secondly, experience with cognitively visualizing scales that do not offer themselves to direct human observation.

Direct experiences: In a study of how a sense of scale develops, most of the respondents suggest that direct experiences such as moving over distances by foot, by bicycle, by car or by plane played a crucial part in the development of their sense of scale for objects that are directly available for humans to experience [11].

Experience with visualizing scales outside direct human observation: Simply being exposed to thinking about and working with scale are experiences that help students become more scale adept. Several authors have pointed out how a sense of scale develops from childhood to adulthood, through repeatedly having both in- and out-of-school experiences dealing with scale [11,15]. Similarly, learning labels for different scales and quantity, as well as developing strategies for measuring, imaging, estimating and using measuring tools are important for this process [11,61]. Through experience, many people develop conceptual anchor points like the size of an atom, density of water, size of body parts, continental and celestial distances to make rapid shifts from one scale to another [11,61]. Cheek [15] also suggests building relevant experience by visualizing different scales of time, space and multitude through students working with and developing their own object- or event-models of entities outside of human direct experience. For example, Janowska et al. [115] found that training students in creative visual imagining is linked with the knowledge and understanding of space, and aids children's understanding of basic astronomical concepts.

Furthermore, dialogic teaching practices (e.g., [65]) might be of particular use for helping students become scale competent on issues related to geography. A feature of dialogic thinking is that students, in conversations with fellow students and/or their teacher, will experience dissonance in their understanding of the issue at hand compared with fellow students or the teacher. Such dissonance can encourage students to consolidate their conceptual models with the current concepts and models of geography. Through classroom dialogue, students will experience the cognitive models that other students have constructed in their meaning making around issues of scale, and to express and reconstruct their own.

In their paper on age and experience-related differences in scale conceptions, Tretter et al. [13] emphasized that to have the ability to conceptualize different scales, one must be able to make cognitive leaps to different cognitive worlds. Consequently, a useful approach for teachers might be to help students think of shifting magnitudes as a journey outside of the realms of direct human perception. 
What follows are some simple rules of thumb for scale-travel in order to become adept at traversing scales outside of human experience:

Be aware of departure: Many of the issues regarding scale in science education might stem from students simply not understanding that they need to make a conceptual shift. That is, they have not understood that it is time to depart from the magnitudes of everyday human direct experiences. Such departures should be announced whenever they happen in the classroom. That is, in order to help students to understand that the part of reality that the scientific story currently being investigated in the classroom is on a scale outside direct experience. Students need to be reminded that they are crossing "borders of magnitudes", that is, this area of natural science requires a shift in which order of magnitude to apply to make sense of it.

Pick your mode of travel: Just as important as understanding that you are leaving magnitudes available for direct experience is the ability to know how to get where you are going. Which modes of travel are at our disposal? That is, what tools are available for scaling our cognitive images up or down to the location outside the sphere of direct experience that we are trying to travel to? These modes of travel can be dialogue, digital tools (see below), digital animations (see below), or different kinds of object or event models.

Know where you are: Constantly being made or making oneself aware of where the student is in relation to our everyday world of experiences is essential for appreciating the qualities offered by the new environment. That is, by which order of magnitude removed from the human experience range of a parameter are we currently trying to conceptualize?

Bring local currency: Unitize is the process of developing a new unit from existing (and understood) objects, in order to make sense of quantitative levels outside of human scales [114]. For example, when working with astronomical distances, introducing the unit of light years helps students conceptualize distances at celestial scales better than working with kilometres or miles [13].

Always bring a good map: It has been suggested that the use of analogies is a method to help students reason with issues of scale [112]. In this context, analogies by comparing something outside of human perception to something within, enables the student to make sense of the entity or process under study. In the same way as using a topographical map to navigate the real world, analogies offer the student something comparable and graspable to tackle the incomprehensible.

Choose your future: Béneker and van der Schee [30] give examples on the benefit of having students building future scenarios. This could make them reflect about what kind of world they want to live in, and to argue, select, discuss and compare alternatives. Being aware of scales and multitudes, shaping future scenarios could be a way to rethink the present critically and actively work for change.

Know how to count: Mathematics and statistics are traditional tools for dealing with scales. Yet, the students find it easier to understand scales and differences when they themselves have counting tasks. When they realize that the $\mathrm{pH}$ scale is logarithmic, which means that an increase or decrease of an integer value changes the concentration by tenfold, makes it understandable why a decrease of $\mathrm{pH}$ in the oceans is such a tremendous problem. Another scale and multitude-related task is to try to assess some of the consequences of the world population doubling over time, or the possible savings accruing from arranging digital events instead of holding face-to-face life gatherings. Walter [33] presents many ideas and good examples of how to use mathematics to understand sustainability issues, and many of them suit geography education.

Comparisons is a way to examine options mathematically. Wilcke and Budke [116] present a systematic step-by-step model on how to use comparisons in secondary education settings. In their example, students compared refugee arrival figures in European countries and lists which elements and what order is required to allow for students to improve their ability to argue, reflect, and promote good judgement. And comparisons, Liu et al. [117] argues, can develop students' higher-order spatial thinking skills, in her case using comparisons of geo-information obtained with GIS-systems. This brings us to the benefits of digital tools when learning about scales in geography. 
Digital tools as scaffolding while becoming scale-adept: "Look! The stars move together $\ldots$ at the same time!" exclaims a 14-year-old student. "And the moon is following along ...," chimes in her classmate. Three science students are watching a time-lapse video of the sky of the previous night and have stumbled on what for them is a novel realization: the stars in the night sky appear to move in concert, from east to west. This sparks off a discussion that effortlessly, and unaided by the teacher, skips between the heliocentric world view, the direction of the Earth's rotation and the nature of the moon's trajectory around the Earth. Then another student points out frequent lights that buzz across the bottom of the view. They agree that the lights are on boats coming and going from the local harbour, and another student exclaims: "I never knew there was so much activity in the harbour ... what are all these ships, where are they going, what cargo are they carrying?"

This is an example of students suddenly seeing patterns around them when given tools that help them move between different magnitudes of time, allowing them to notice phenomena appearing on a slower time scale than they would usually notice. The students in question became engaged and curious and had become aware of patterns that they could have seen every starlight night they might have experienced, but which evaded detection because it happens at such a slow rate. They may have seen videos like this before, but in a world of digital special effects, who will believe anything? However, in this time-lapse movie which they had shot and produced themselves, they saw the silhouette of their home village in the lower part of the screen. It is as real as it gets, they were able to discover a pattern in nature, and they eagerly made sense of it using bits and pieces that each of them brought to the table of what they already know in order to talk their way towards an explanation of what they captured. And they noticed something about human activity and commerce in their home village previously unknown to them: cargo vessels shipping goods to and from the world.

One would assume that spending time in settings that allow students to move between different orders of magnitude on scales of time, space and quantity, to be a helpful exercise in getting used to mentally visualizing scales outside of human direct experience. Being unable to see very slow or very fast processes is a common challenge of scale in science education. Similarly, being unable to zoom in very close or to be able to get a broader overview is also an issue of scale. Easily available digital tools such as cameras, digital microscopes and camera equipped drones can enable students to make brief trips to the neighbourhoods outside of their everyday experiences.

Slowing down or speeding up time with slow-motion and time-lapse-photography respectively, can be an effective way to make students observe and make sense of slow or fast processes they had previously been unaware of. This can include fast processes such as chemical reactions and measurements of velocity, and slow processes such as tidal movement, plant growth, snail movements and seasonal variations. Such exercises can develop students understanding of and relationship to nature, an important component of sustainability education.

Additionally, digital tools offer a host of visual models, static, animated and interactive, that can help students become more scale-adept in sustainability issues. For example, serious games, that is, games created "to have underlying objectives beyond mere entertainment such as instructional goals" [118], can provide students with simulations that can make them experienced at imagining processes, scenarios and dilemmas on scales of time, space and multitude outside of their everyday experiences (e.g., [11]). Map services such as Google Earth ${ }^{\mathrm{TM}}$ and others and a host of animations on virtually any geography related sustainability topic touched upon in this paper are currently available online. This also includes virtual reality approaches to visualizing aspects of reality outside of direct human physical experience [119].

\section{Conclusions}

The purpose of this paper has been to point out how most of the common alternative conceptions held by students within sustainability topics in geography education are related to issues of scale. That is, how students make sense of different magnitudes of particularly time, space and multitude appears to be the cause of many alternative conceptions within sustainability thinking in geography 
education. Furthermore, we have presented several educational approaches and tools that previous studies have emphasized in scale-related education, and we have suggested several novel approaches. One example is slow-motion and time-lapse functions of digital cameras as easily accessible tools to allow students to experience and develop familiarity with processes and features that are too fast, slow, large or small to be experienced directly.

We have chosen to apply the issue of scale to novel topics within sustainability education in geography, such as the reach of empathy, alternative futures and the issue of greenwashing efforts. These are core issues in sustainability education, and the ability to grasp the concept of scale will influence students' deep understanding of sustainability thinking on a local, global level and even universe-level. In addition, they start to reflect critically on sustainability issues from both personal and collective perspectives.

Author Contributions: Conceptualization, F.S. and L.-A.W.; methodology, F.S. and L.-A.W.; investigation, F.S. and L.-A.W.; writing — original draft preparation, F.S. and L.-A.W.; writing-review and editing, F.S. and L.-A.W.; project administration, F.S. All authors have read and agreed to the published version of the manuscript.

Funding: This research received no external funding.

Acknowledgments: We would like to thank Tuula Skarstein for good discussions on the topics of scale, ESD and digital tools before and during the writing of this paper.

Conflicts of Interest: The authors declare no conflict of interest.

\section{References}

1. Samuel, S. A Staggering 1 Billion Animals are now Estimated Dead in Australia's Fires. Vox.com, 7 January 2020.

2. BBC News. Australia Fires: A Visual Guide to the Bushfire Crisis. BBC News, 10 January 2020.

3. Ross, A. How Global Media Views the Australian Bushfires. The Advertiser, 6 January 2020.

4. Gunia, A.; Law, T. At Least 24 People and Millions of Animals Have Been Killed by Australia's Bushfires. TIME, 7 January 2020.

5. Crutzen, P.J. The "anthropocene". In Earth System Science in the Anthropocene; Springer: Berlin/Heidelberg, Germany, 2006; pp. 13-18.

6. Hamilton, C. Defiant Earth: The Fate of Humans in the Anthropocene; John Wiley \& Sons: Hoboken, NJ, USA, 2017.

7. Lewis, S.; Maslin, M. Human Planet: How We Created the Anthropocene; Yale University Press: London, UK, 2018.

8. Benatar, S.; Upshur, R.; Gill, S. Understanding the relationship between ethics, neoliberalism and power as a step towards improving the health of people and our planet. Anthr. Rev. 2018, 5, 155-176. [CrossRef]

9. Rieckmann, M. Education for Sustainable Development Goals: Learning Objectives; UNESCO Publishing: Paris, France, 2017.

10. Rosling, H.; Rönnlund, A.R.; Rosling, O. Factfulness: Ten Reasons We're Wrong about the World-And Why Things are Better Than You Think; Flatiron Books: New York, NY, USA, 2018.

11. Jones, M.G.; Taylor, A.R. Developing a sense of scale: Looking backward. J. Res. Sci. Teach. Off. J. Natl. Assoc. Res. Sci. Teach. 2009, 46, 460-475. [CrossRef]

12. American Association for the Advancement of Science. Science for all Americans; Oxford University Press: Oxford, UK, 1990.

13. Tretter, T.R.; Jones, M.G.; Minogue, J. Accuracy of scale conceptions in science: Mental maneuverings across many orders of spatial magnitude. J. Res. Sci. Teach. 2006, 43, 1061-1085. [CrossRef]

14. Montello, D.R. Scale in Geography; Springer: Berlin/Heidelberg, Germany, 2001.

15. Cheek, K.A.; LaDue, N.D.; Shipley, T.F. Learning about spatial and temporal scale: Current research, psychological processes, and classroom implications. J. Geosci. Educ. 2017, 65, 455-472. [CrossRef]

16. Lambert, D.; Morgan, J. Teaching Geography 11-18: A Conceptual Approach: A Conceptual Approach; McGraw-Hill Education (UK): Maidenhead, UK, 2010.

17. Pyle, C. Teaching the time: Physical geography in four dimensions. Teach. Geogr. 2007, 32, 121. 
18. Kemmis, S.; Mutton, R. Education for sustainability (EfS): Practice and practice architectures. Environ. Educ. Res. 2012, 18, 187-207. [CrossRef]

19. Tilbury, D. Emerging issues in education for sustainable development. Educ. Sustain. Dev. Nepal: Views Vis. 2003, 29, 29-40.

20. Wolff, L.-A. Education for sustainable development needs a critical approach. In Proceedings of International Conference on Environmental Education; University of Helsinki: Helsinki, Finland, 2006; pp. 29-46.

21. Vare, P.; Scott, W. Learning for a change: Exploring the relationship between education and sustainable development. J. Educ. Sustain. Dev. 2007, 1, 191-198. [CrossRef]

22. Smith, M. How does education for sustainable development relate to geography education. In Debates in Geography Educaiton; Routledge: London, UK, 2013; pp. 257-269.

23. Sprenger, S.; Nienaber, B. (Education for) Sustainable Development in Geography Education: review and outlook from a perspective of Germany. J. Geogr. High. Educ. 2018, 42, 157-173. [CrossRef]

24. Chalkley, B.; Blumhof, J.; Ragnarsdóttir, K.V. Geography, earth and environmental sciences: A suitable home for ESD? In Sustainability Education; Routledge: London, UK, 2010; pp. 108-122.

25. Fisher, C.; Binns, T. Issues in Geography Teaching; Routledge: London, UK, 2016.

26. Gersmehl, P. Teaching Geography; Guilford Publications: New York, NY, USA, 2014.

27. Lawson, V. Making Development Geography; Routledge: London, UK, 2014.

28. Solem, M.; Lambert, D.; Sirpa, T. Geocapabilities: Toward an international framework for researching the purposes and values of geography education. Rev. Int. Geogr. Educ. Online 2013, 3, 214-229.

29. Lambert, D.; Solem, M.; Tani, S. Achieving human potential through geography education: A capabilities approach to curriculum making in schools. Ann. Assoc. Am. Geogr. 2015, 105, 723-735. [CrossRef]

30. Béneker, T.; van der Schee, J. Future geographies and geography education. Int. Res. Geogr. Environ. Educ. 2015, 24, 287-293. [CrossRef]

31. Lambert, D.; Balderstone, D. Learning to Teach Geography in the Secondary School: A Companion to School Experience; Routledge: London, UK, 2012.

32. Wellens, J.; Berardi, A.; Chalkley, B.; Chambers, B.; Healey, R.; Monk, J.; Vender, J. Teaching geography for social transformation. J. Geogr. High. Educ. 2006, 30, 117-131. [CrossRef]

33. Walter, M. Mathematics for the Environment; CRC Press: Boca Raton, FL, USA, 2011.

34. Robertson, M.E. Geography Education Responding to Global Forces: Redefining the Territory. In Geography Education for Global Understanding; Springer: Berlin/Heidelberg, Germany, 2018; pp. 13-28.

35. Klein, P.; Pawson, E.; Solem, M.; Ray, W. Geography education for "an attainable global perspective". J. Geogr. High. Educ. 2014, 38, 17-27. [CrossRef]

36. Fox, T.; Pope, M.; Ellis, E.C. Engineering the Anthropocene: Scalable social networks and resilience building in human evolutionary timescales. Anthr. Rev. 2017, 4, 199-215. [CrossRef]

37. Widener, J.M.; Gliedt, T.; Tziganuk, A. Assessing sustainability teaching and learning in geography education. Int. J. Sustain. High. Educ. 2016, 17, 698-718. [CrossRef]

38. Encyclopedia Britannica. Space. Available online: https:/www.britannica.com/science/space-physics-andmetaphysics (accessed on 6 December 2019).

39. Saar, M.; Palang, H. The dimensions of place meanings. Living Rev. Landsc. Res. 2009, 3, 5-24. [CrossRef]

40. Aristotle. Physics. In Internet Classics Archive; Massachusetts Institute of Technology: Cambridge, MA, USA, 2009.

41. Chrystal, D. Talking about time. In Time; Ridderbos, K., Ed.; Cambridge University Press: Cambridge, UK, 2002; pp. 105-125.

42. Isham, C.J.; Savvidou, N. Time and modern physics. Time 2002, 14, 6.

43. Roark, T. Aristotle on Time: A study of the Physics; Cambridge University Press: Cambridge, UK, 2011.

44. Leicht, A.; Heiss, J.; Byun, W.J. Issues and Trends in Education for Sustainable Development; UNESCO Publishing: Paris, France, 2018; Volume 5.

45. Wiek, A.; Bernstein, M.; Foley, R.; Cohen, M.; Forrest, N.; Kuzdas, C.; Kay, B.; Withycombe Keeler, L. Operationalising competencies in higher education for sustainable development. Handb. High. Educ. Sustain. Dev. RoutledgeLond. 2015, 241-260.

46. Wiek, A.; Withycombe, L.; Redman, C.L. Key competencies in sustainability: A reference framework for academic program development. Sustain. Sci. 2011, 6, 203-218. [CrossRef] 
47. Koning, J. Social sustainability in a globalizing world: context, theory and methodology explored. In Proceedings of the UNESCO/MOST Meeting, The Hague, The Netherlands, 1 November 2001; pp. $22-23$.

48. Marston, S.A.; Jones, J.P., III; Woodward, K. Human geography without scale. Trans. Inst. Br. Geogr. 2005, 30, 416-432. [CrossRef]

49. UNFPA; UNDESA; UN-HABITAT; IOM. Population Dynamics in the Post-2015 Development Agenda: Report of the Global Thematic Consultation on Population Dynamics. United Nations. Available online: https://www. unfpa.org/sites/default/files/pub-pdf/Population\%20Dynamics\%20in\%Post-2015\%20FINAL.pdf (accessed on 21 December 2019).

50. GÜNEY, T. Population growth and sustainable development in developed-developing countries: An iv (2SLS) approach. Suleyman Demirel Univ. J. Fac. Econ. Adm. Sci. 2017, 22, 1255-1277.

51. Siegel, F.R. Countering 21st Century Social-Environmental Threats to Growing Global Populations; Springer: Berlin/Heidelberg, Germany, 2014.

52. UNDP. Human Development Report 2019: Beyond Income, Beyond Averages, Beyond Today: Inequalities in Human Development in the 21st Century; UNDP: New York, NY, USA, 2019.

53. Wells, J. Complexity and Sustainability; Routledge: London, UK, 2012.

54. Pickrell, J. Australia's vulnerable species hit hard by fires. Science 2019, 366, 1427-1428. [CrossRef] [PubMed]

55. Carleton, T.A.; Hsiang, S.M. Social and economic impacts of climate. Science 2016, 353, aad9837. [CrossRef]

56. Schmidt, J.J.; Brown, P.G.; Orr, C.J. Ethics in the Anthropocene: A research agenda. Anthr. Rev. 2016, 3, 188-200. [CrossRef]

57. Zambon, I.; Rontos, K.; Serra, P.; Colantoni, A.; Salvati, L. Population Dynamics in Southern Europe: A Local-Scale Analysis, 1961-2011. Sustainability 2019, 11, 109. [CrossRef]

58. Dawkins, R. Why the universe seems so strange. In TEDGlobal 2005; TED Talks: New York, NY, USA, 2005.

59. Jones, M.G.; Paechter, M.; Yen, C.-F.; Gardner, G.; Taylor, A.; Tretter, T. Teachers' concepts of spatial scale: An international comparison. Int. J. Sci. Educ. 2013, 35, 2462-2482. [CrossRef]

60. Jones, M.G.; Tretter, T.; Taylor, A.; Oppewal, T. Experienced and novice teachers' concepts of spatial scale. Int. J. Sci. Educ. 2008, 30, 409-429. [CrossRef]

61. Tretter, T.R.; Jones, M.G.; Andre, T.; Negishi, A.; Minogue, J. Conceptual boundaries and distances: Students' and experts' concepts of the scale of scientific phenomena. J. Res. Sci. Teach. Off. J. Natl. Assoc. Res. Sci. Teach. 2006, 43, 282-319. [CrossRef]

62. Gilbert, J.K.; Watts, D.M. Concepts, misconceptions and alternative conceptions: Changing perspectives in science education. Stud. Sci. Educ. 1983, 10, 61-98. [CrossRef]

63. Lane, R. Students' alternative conceptions in geography. Geogr. Educ. 2008, 21, 43.

64. Driver, R. Pupils' alternative frameworks in science. Eur. J. Sci. Educ. 1981, 3, 93-101. [CrossRef]

65. Mortimer, E.; Scott, P. Meaning Making In Secondary Science Classrooms; McGraw-Hill Education (UK): Maidenhead, UK, 2003.

66. Smith, J.P., III; Disessa, A.A.; Roschelle, J. Misconceptions reconceived: A constructivist analysis of knowledge in transition. J. Learn. Sci. 1994, 3, 115-163. [CrossRef]

67. Dove, J. Reasons for misconceptions in physical geography. Geography 2016, 101, 47.

68. Lane, R.; Coutts, P. Working with Students' Ideas in Physical Geography: A Model of Knowledge Development and Application. Geogr. Educ. 2015, 28, 27-40.

69. Francek, M. A compilation and review of over 500 geoscience misconceptions. Int. J. Sci. Educ. 2013, 35, 31-64. [CrossRef]

70. Obermaier, G.; Schrüfer, G. Personal concepts on “Hunger in Africa”. Int. Res. Geogr. Environ. Educ. 2009, 18, 245-251. [CrossRef]

71. Reinfried, S.; Aeschbacher, U.; Rottermann, B. Improving students' conceptual understanding of the greenhouse effect using theory-based learning materials that promote deep learning. Int. Res. Geogr. Environ. Educ. 2012, 21, 155-178. [CrossRef]

72. Chang, C.-H.; Pascua, L. Singapore students' misconceptions of climate change. Int. Res. Geogr. Environ. Educ. 2016, 25, 84-96. [CrossRef]

73. Ocal, A.; Kisoglu, M.; Alas, A.; Gurbuz, H. Turkish prospective teachers' understanding and misunderstanding on global warming. Int. Res. Geogr. Environ. Educ. 2011, 20, 215-226. [CrossRef] 
74. Arslan, H.O.; Cigdemoglu, C.; Moseley, C. A three-tier diagnostic test to assess pre-service teachers' misconceptions about global warming, greenhouse effect, ozone layer depletion, and acid rain. Int. J. Sci. Educ. 2012, 34, 1667-1686. [CrossRef]

75. Harrington, J. Misconceptions: Barriers to improved climate literacy. Phys. Geogr. 2008, 29, 575-584. [CrossRef]

76. Koch, S.; Barkmann, J.; Sundawati, L.; Bögeholz, S. Subjective theories of Indonesian agronomy and biology teacher students on environmental commons dilemmas. Int. Res. Geogr. Environ. Educ. 2013, 22, 120-138. [CrossRef]

77. Capstick, S.; Whitmarsh, L.; Poortinga, W.; Pidgeon, N.; Upham, P. International trends in public perceptions of climate change over the past quarter century. Wiley Interdiscip. Rev. Clim. Chang. 2015, 6, 35-61. [CrossRef]

78. Goebbert, K.; Jenkins-Smith, H.C.; Klockow, K.; Nowlin, M.C.; Silva, C.L. Weather, climate, and worldviews: The sources and consequences of public perceptions of changes in local weather patterns. WeatherClim. Soc. 2012, 4, 132-144. [CrossRef]

79. Hoffman, A.J. How Culture Shapes the Climate Change Debate; Stanford University Press: Stanford, CA, USA, 2015.

80. McCright, A.M.; Dunlap, R.E. The politicization of climate change and polarization in the American public's views of global warming, 2001-2010. Sociol. Q. 2011, 52, 155-194. [CrossRef]

81. McCright, A.M.; Dunlap, R.E.; Marquart-Pyatt, S.T. Political ideology and views about climate change in the European Union. Environ. Politics 2016, 25, 338-358. [CrossRef]

82. Hornsey, M.J.; Harris, E.A.; Bain, P.G.; Fielding, K.S. Meta-analyses of the determinants and outcomes of belief in climate change. Nat. Clim. Chang. 2016, 6, 622. [CrossRef]

83. Lee, T.M.; Markowitz, E.M.; Howe, P.D.; Ko, C.-Y.; Leiserowitz, A.A. Predictors of public climate change awareness and risk perception around the world. Nat. Clim. Chang. 2015, 5, 1014. [CrossRef]

84. Poortinga, W.; Whitmarsh, L.; Steg, L.; Böhm, G.; Fisher, S. Climate change perceptions and their individual-level determinants: A cross-European analysis. Glob. Environ. Chang. 2019, 55, 25-35. [CrossRef]

85. Groves, F.H.; Pugh, A.F. Elementary Pre-Service Teacher Perceptions of the Greenhouse Effect. J. Sci. Educ. Technol. 1999, 8, 75-81. [CrossRef]

86. Elsasser, S.W.; Dunlap, R.E. Leading voices in the denier choir: Conservative columnists' dismissal of global warming and denigration of climate science. Am. Behav. Sci. 2013, 57, 754-776. [CrossRef]

87. Ramus, C.A.; Montiel, I. When are corporate environmental policies a form of greenwashing? Bus. Soc. 2005, 44, 377-414. [CrossRef]

88. Laufer, W.S. Social accountability and corporate greenwashing. J. Bus. Ethics 2003, 43, 253-261. [CrossRef]

89. Van Halderen, M.D.; Bhatt, M.; Berens, G.A.; Brown, T.J.; Van Riel, C.B. Managing impressions in the face of rising stakeholder pressures: Examining oil companies' shifting stances in the climate change debate. J. Bus. Ethics 2016, 133, 567-582. [CrossRef]

90. Cherry, M.A.; Sneirson, J.F. Chevron, Greenwashing, and the Myth of'Green Oil Companies'. J. EnergyClim. Environ. 2012, 3, 22.

91. Ihlen, $\varnothing$. The oxymoron of 'sustainable oil production': the case of the Norwegian oil industry. Bus. Strategy Environ. 2009, 18, 53-63. [CrossRef]

92. Sæther, A.K. De Beste Intensjoner-Oljelandet $i$ Klimakampen [Translated to English: With the Best Intentions-the Oil Country in the Climate Battle.]; Cappelen-Damm: Oslo, Norway, 2017; p. 511.

93. Oreskes, N.; Conway, E.M. Merchants of Doubt: How a Handful of Scientists Obscured the Truth on Issues From Tobacco Smoke to Global Warming; Bloomsbury Publishing: London, UK, 2011.

94. Masnadi, M.S.; El-Houjeiri, H.M.; Schunack, D.; Li, Y.; Englander, J.G.; Badahdah, A.; Monfort, J.-C.; Anderson, J.E.; Wallington, T.J.; Bergerson, J.A. Global carbon intensity of crude oil production. Science 2018, 361, 851-853. [CrossRef]

95. Soga, M.; Gaston, K.J. Shifting baseline syndrome: causes, consequences, and implications. Front. Ecol. Environ. 2018, 16, 222-230. [CrossRef]

96. Meyfroidt, P. Environmental cognitions, land change, and social-ecological feedbacks: An overview. J. Land Use Sci. 2013, 8, 341-367. [CrossRef]

97. Essl, F.; Dullinger, S.; Rabitsch, W.; Hulme, P.E.; Pyšek, P.; Wilson, J.R.; Richardson, D.M. Delayed biodiversity change: no time to waste. Trends Ecol. Evol. 2015, 30, 375-378. [CrossRef] [PubMed] 
98. Clavero, M. Shifting baselines and the conservation of non-native species. Conserv. Biol. 2014, 28, 1434-1436. [CrossRef]

99. Dayton, P.K.; Tegner, M.J.; Edwards, P.B.; Riser, K.L. Sliding baselines, ghosts, and reduced expectations in kelp forest communities. Ecol. Appl. 1998, 8, 309-322. [CrossRef]

100. Turner, W.R. Where are Tucson's Birds? Multiscale Models, Shifting Baselines, and Alternative Futures. Ph.D. Thesis, The University of Arizona, Tucson, AZ, USA, 2003.

101. Gray, J.; Dautel, H.; Estrada-Peña, A.; Kahl, O.; Lindgren, E. Effects of climate change on ticks and tick-borne diseases in Europe. Interdiscip. Perspect. Infect. Dis. 2009, 2009. [CrossRef]

102. Pyhälä, A.; Fernández-Llamazares, Á.; Lehvävirta, H.; Byg, A.; Ruiz-Mallén, I.; Salpeteur, M.; Thornton, T.F. Global environmental change: local perceptions, understandings, and explanations. Ecol. Soc. A J. Integr. Sci. Resil. Sustain. 2016, 21, 25. [CrossRef]

103. Selim, S. Shifting Baselines in Coastal Ecosystem Service Provision; University of Sheffield: England, UK, 2015.

104. Máñez, K.S.; Poulsen, B. Of seascapes and people: multiple perspectives on oceans past. In Perspectives on Oceans Past; Springer: Dordrecht, The Netherlands, 2016; pp. 1-10.

105. Hirsch, S.L. Anticipatory practices: Shifting baselines and environmental imaginaries of ecological restoration in the Columbia River Basin. Environ. Plan. E Nat. Space 2019, 2514848619857523. [CrossRef]

106. Forbes, C.J.; Gillson, L.; Hoffman, M.T. Shifting baselines in a changing world: Identifying management targets in endangered heathlands of the Cape Floristic Region, South Africa. Anthropocene 2018, 22, 81-93. [CrossRef]

107. Pauly, D. Anecdotes and the shifting baseline syndrome of fisheries. Trends Ecol. Evol. 1995, 10, 430. [CrossRef]

108. Papworth, S.K.; Rist, J.; Coad, L.; Milner-Gulland, E.J. Evidence for shifting baseline syndrome in conservation. Conserv. Lett. 2009, 2, 93-100. [CrossRef]

109. Plumeridge, A.A.; Roberts, C.M. Conservation targets in marine protected area management suffer from shifting baseline syndrome: A case study on the Dogger Bank. Mar. Pollut. Bull. 2017, 116, 395-404. [CrossRef]

110. Craig, R.K. Perceiving Change and Knowing Nature: Shifting Baselines and Nature's Resiliency. In Environmental Law and Contrasting Ideas of Nature: A Constructivist Approach; Hirokawa, K., Ed.; Cambridge University Press: Cambridge, UK, 2015; pp. 87-111.

111. Klein, E.S.; Thurstan, R.H. Acknowledging long-term ecological change: The problem of shifting baselines. In Perspectives on Oceans Past; Springer: Dordrecht, The Netherlands, 2016; pp. 11-29.

112. Resnick, I.; Davatzes, A.; Newcombe, N.S.; Shipley, T.F. Using analogy to learn about phenomena at scales outside human perception. Cogn. Res. Princ. Implic. 2017, 2, 21. [CrossRef] [PubMed]

113. O'Sullivan, D. Exploring Spatial Scale in Geography. Int. J. Geogr. Inform. Sci. 2015, 29, 1932-1933. [CrossRef]

114. Lamon, S.J. Teaching Fractions and Ratios for Understanding: Essential Content Knowledge and Instructional Strategies for Teachers; Routledge: London, UK, 2012.

115. Jankowska, D.M.; Gajda, A.; Karwowski, M. How children's creative visual imagination and creative thinking relate to their representation of space. Int. J. Sci. Educ. 2019, 41, 1096-1117. [CrossRef]

116. Wilcke, H.; Budke, A. Comparison as a Method for Geography Education. Educ. Sci. 2019, 9, 225. [CrossRef]

117. Liu, R.; Greene, R.; Li, X.; Wang, T.; Lu, M.; Xu, Y. Comparing Geoinformation and Geography Students' Spatial Thinking Skills with a Human-Geography Pedagogical Approach in a Chinese Context. Sustainability 2019, 11, 5573. [CrossRef]

118. Wu, J.S.; Lee, J.J. Climate change games as tools for education and engagement. Nat. Clim. Chang. 2015, 5, 413. [CrossRef]

119. Moreno, R.; Mayer, R.E. Learning science in virtual reality multimedia environments: Role of methods and media. J. Educ. Psychol. 2002, 94, 598. [CrossRef]

(C) 2020 by the authors. Licensee MDPI, Basel, Switzerland. This article is an open access article distributed under the terms and conditions of the Creative Commons Attribution (CC BY) license (http://creativecommons.org/licenses/by/4.0/). 